\title{
Labour Market Responsiveness of Greek Apprenticeships: An Empirical Investigation
}

\author{
Varvara Lalioti \\ Democritus University of Thrace, Department of Social Administration and Political Science, \\ Komotini - Greece - blalioti@gmail.com
}

\begin{abstract}
The ongoing economic crisis in Greece has themes associated with a key aspect of apprengiven rise to a new interest in apprenticeships, linked to the perception that such programmes can provide an alternative to an academic educational pathway that can boost the employment prospects of young people. Against this background and drawing on the findings of a large-scale, mostly qualitative, research project that reviewed the Greek apprenticeship system and involved surveying 150 stakeholders, this original exploratory article provides a critical, succinct, but also comprehensive exploration of three major ticeships in Greece: labour market responsiveness. These themes which emerged from the thematic content analysis undertaken, are: (i) content-related issues; (ii) actor-related issues; and (iii) issues related to the mismatch between the offer of and demand for apprenticeship positions. The article argues that, despite some strengths, serious weaknesses jeopardize the potential of apprenticeships in Greece to function as an effective alternative to academic study and an efficient path towards labour market integration.
\end{abstract}

Keywords: Labour market responsiveness, apprenticeships, vocational education and training,

Greece, crisis.

\section{A Capacidade de Resposta do Mercado de Trabalho para a Formação Profissional na Grécia: Uma Investigação Empírica}

\section{Sumário}

A crise económica atual na Grécia deu origem a um novo interesse pela formação profissional, o que está ligado à perceção de que os programas de formação profissional podem fornecer uma alternativa a um percurso educativo académico e que podem impulsionar as perspetivas de emprego para os jovens. Nes- te contexto e com base nos resultados de um projeto de pesquisa de grande escala, maioritariamente qualitativo, que analisou o sistema de formação grego e envolveu um questionário a 150 stakeholders, este artigo exploratório original fornece uma exploração crítica sucinta, mas também compreensiva de três gran- 
des temas associados a um aspeto chave da formação profissional na Grécia: a capacidade de resposta do mercado de trabalho. Estes temas que emergiram da análise do conteúdo do tema são: (i) questões relacionadas com o conteúdo; (ii) questões relacionadas com os intervenientes; e (iii) questões relacionadas com o desequilíbrio entre a oferta e a pro- cura por cargos com formação profissional. Este artigo argumenta que, apesar de algumas forças, existem sérias fraquezas que prejudicam o potencial da formação profissional na Grécia em funcionar como uma alternativa efetiva aos estudos académicos e como um caminho eficiente na direção da integração no mercado de trabalho.

Palavras-chave: Capacidade de resposta do mercado de trabalho, Formação Profissional, Ensino Vocacional e estágio, Grécia, crise.

\section{INTRODUCTION}

Drawing on the findings of a large-scale, mostly qualitative research project, this article breaks new ground in exploring, from a multi-stakeholder perspective, the key issue of the labour market responsiveness of the Greek apprenticeship system. In the midst of the Greek financial crisis, the youth unemployment rate increased dramatically from $22.7 \%$ in 2007 to $52.4 \%$ in 2014 (falling back slightly to $47.3 \%$ in 2016), and led to an extensive 'brain drain'. Against this background, apprenticeships have attracted attention as an alternative to an academic educational pathway that can boost the employment prospects of young people.

Indeed, statistical data indicate that approximately $70 \%$ of graduates of apprenticeship programmes in Greece enter employment upon completion of their studies (Ministry of Labour, Social Insurance and Welfare, 2015, pp. 13-18). The figure is even higher in specialties such as IT. Similarly, at the European level, 60 to $70 \%$ of apprentices move into a job directly following their studies, while in some employment sectors this rises to as much as 90\% (European Commission, 2017).

The recent attention paid by the Greek authorities to apprenticeships is in line with the central position apprenticeships occupy in the discussion on restructuring education in Europe. It contrasts with the previously low level of interest in these programmes, and the traditional underdevelopment of the Greek vocational education and training (VET) system, of which apprenticeships form one part.

References to recent policy initiatives related to apprenticeships are included in the 2015 Economic Adjustment Programme (European Commission, 2015), the National Strategic Framework for Upgrading VET (Law 4386/2016), and, most evidently, 
in the Quality Framework for Apprenticeships (QFA) (Joint Ministerial Decision no. 26385/20 February 2017). The changes that have been introduced include, inter alia, the extension of higher apprenticeships. These have been offered at post-secondary level, since 2016 by the EPAL, i.e., vocational education schools operating under the aegis of the Ministry of Education, Research and Religious Affairs. Participation in the EPAL apprenticeship programmes leads to qualifications at level 5 of the national and European qualification frameworks (NQF and EQF) after one year of school and workplace training.

Nonetheless, the Manpower Employment Organization (OAED), i.e., the Greek public employment agency remains the main provider of higher apprenticeships in Greece. OAED is currently responsible for 51 vocational education schools (commonly known as EPAS). The EPAS operate at upper secondary level, under the aegis of the Ministry of Labour, Social Insurance and Solidarity, and cater for students aged 16 to 23 , who must have completed at least the first class of upper secondary school. They provide apprenticeships in specialties such as silversmithing, bakery and pastry-making, and hairdressing, leading to qualifications at NQF/EQF level 4 after two years of school and workplace training. It is these OAED apprenticeship programmes and their labour market responsiveness, i.e., the extent to which the programmes on offer adapt and change in response to changes in the labour market, that are the focus of the present article.

Labour market responsiveness is one of the central themes examined in the apprenticeship-related literature covering countries with a strong apprenticeship tradition, such as Austria, Germany, Switzerland, Denmark and the Netherlands. In general, there is a consensus that apprenticeships ease the school-to-work transition and lower the unemployment rate (see e.g. Wolter \& Ryan, 2011; Piopiunik \& Ryan, 2012). Some commentators, however, argue that the labour market advantages gained by apprentices are transitory and fade over time (see e.g. Parey, 2016), or that they mainly benefit those placed in large firms (see e.g. Albanese, Cappellari, \& Leonardi, 2017).

Content-related issues, actor-related issues, and the match between the offer of and demand for apprenticeship placements are the main three topics which emerged from the thematic analysis undertaken as part of the research presented here. These issues are amongst the main topics explored in the context of the above literature. The relationship between the 'content' of training, as exemplified by the characteristics of the school- and company-based components of apprenticeships, and the 'success' of apprenticeships, as measured by the rate of labour market integration of graduates, 
is examined. High quality content, e.g. up-to-date curricula and specialties, is recognized as being important to improving the employment prospects of apprentices (see e.g. Fuller, Unwin, Cavaglia, McNally, \& Ventura, 2017).

Content-related difficulties, for example, an 'unpleasant working environment', also arguably explain the limited success of apprenticeships better than factors associated with, for instance, the socio-demographic and educational characteristics of apprentices (see e.g. Gambin, Hogarth, \& Hasluck, 2011). Moreover, the recent financial crisis in Greece is argued to have adversely affected the content of apprenticeships, as well as the attitudes of companies towards them (Bellmann, Gerner, \& Leber, 2014).

Actor-related issues are likewise regarded as having an impact on the labour market responsiveness of apprenticeships. Broadly speaking, governance structures that are deemed helpful in terms of labour market responsiveness rely on the engagement of and close cooperation between key actors. By contrast, the low involvement or commitment of actors with a deep knowledge of the labour market, such as social partners, is seen as being problematic. The need to rethink traditional roles and boundaries, such as the almost exclusive responsibility of state authorities for schoolbased learning, is one of the main arguments put forward in the literature (see e.g. OECD, 2014, pp. 7, 13, 16). To this end, employers are viewed as suitable actors for assuming more extensive roles in apprenticeships (see e.g. Rowe, Moss, Moore, \& Perrin, 2017).

Similarly, the mismatch between the offer of and demand for apprenticeship placements that characterizes various apprenticeship systems, as reflected in the provision of specialties that do not respond to company needs, is perceived as a major obstacle to labour market responsiveness (see e.g. Hogarth, Gambin, \& Hasluck, p. 53). This mismatch should be viewed in conjunction with employer concerns about the quality of graduates and unmet expectations about their skill levels, e.g. the expectation that apprentices will already have specialist occupational skills (see e.g. Grollmann, Steedman, Jansen, \& Gray, 2017).

By contrast, the labour market responsiveness of apprenticeships in Greece is a relatively unexplored subject, leaving ample scope for research. While apprenticeships have been examined in the context of the country's VET strategy (see e.g. Small Enterprises Institute of the Hellenic Confederation of Professionals, Craftsmen, \& Merchants, 2014), specific references to labour market responsiveness are limited.

For instance, Paidoussi (2014) argues that the links between apprenticeships and 
the labour market in Greece are rather weak. A 2015 study by the Foundation for Economic and Industrial Research (IOBE) revealed that apprenticeships increase the likelihood of the integration of graduates into the labour market, but that companies are facing difficulties - related to the financial crisis - that have had an impact on the apprenticeships offered. That same year, the Ministry of Labour published a study that drew attention to the mismatch between the specialty preferences of apprentices and labour market needs and highlighted the lack of adequate technical equipment as a feature that hindered schools from incorporating new specialties into their programmes (Ministry of Labour, Social Insurance and Welfare, 2015, pp. 41-46).

Against this backdrop, this exploratory article aims to fill a significant gap in the literature, by adding to the long tradition of studies outside Greece, which have offered evaluation of apprenticeships based on the views of stakeholders (see e.g. Mulkeen, Abdou, Leigh, \& Ward, 2017). The article argues that, despite some strengths, apprenticeships in Greece also have serious weaknesses. These undermine the potential of apprenticeships to function as an alternative to an academic educational pathway that can boost the employment prospects of young people.

The remainder of the article comprises three main sections covering research methodology, findings, and discussion and conclusions.

\section{RESEARCH METHODOLOGY}

The findings presented draw on a large-scale, mainly qualitative, research project (December 2015-March 2017) that aimed to review the Greek apprenticeship system, using an analytical framework developed by the European Centre for the Development of Vocational Training (known as Cedefop). This framework covered ten thematic areas, including thematic areas such as the place of apprenticeships in the VET system and labour market responsiveness (Cedefop, 2015).

The aim of the research was to uncover stakeholders' perceptions, opinions and experiences with respect to the labour market responsiveness of apprenticeships in Greece. The ultimate objective was to identify strengths and weaknesses and offer suggestions for improvements.

The project commenced with extensive desk research on the state of apprenticeships in Greece. This was followed by three consecutive rounds of fieldwork, which 


\section{Labour Market Responsiveness of Greek Apprenticeships: An Empirical Investigation}

surveyed 150 stakeholders $^{1}$. The sampling method, which aimed to ensure the best possible representativeness of stakeholders, involved a three-stage process designed to ensure an appropriate spread of interviews across regions, economic sectors and target groups (e.g. national agencies, social partners, employers, teachers, students, etc). Selected individuals were invited to take part. They were provided with relevant information and informed consent was obtained.

The first fieldwork round (April-June 2016) collected factual information from implementation-level stakeholders (practitioners and beneficiaries). A total of 100 semi-structured interviews with individuals representing different groups was carried out (27 students, 15 graduates, 23 teachers and school directors, 33 company representatives and two OAED employees). This stage of the work concluded with a round-table discussion with ten participants.

Building on the findings of the first fieldwork round, a second round of interviews (September-October 2016) focused on the challenges identified in the previous round and the current and possible future roles of the institutions involved in apprenticeships in the provision of quality programmes. A total of 35 semi-structured interviews was carried out (with 22 representatives of the national agencies involved in apprenticeships, 11 social partners and two experts in apprenticeship programmes), along with an online survey of 828 employers. Interviewees from this round also participated in a round-table discussion. This took place in November 2016 and examined selected topics that emerged during the second round of fieldwork.

The third fieldwork round (January-February 2017) explored possible solutions and recommendations for improving apprenticeships. It consisted of five semi-structured interviews (with three policy-makers, one representative of social partners and one expert in apprenticeship programmes), and two round-table discussions. The first discussion gathered together six representatives of social partners and chambers of industry and commerce, while the second involved 12 representatives from government ministries and national agencies engaged in the apprenticeship system.

Labour market responsiveness was examined most systematically during the first survey round. Guided by Cedefop's analytical framework, the research examined a series of operational descriptors, such as procedures that allow apprenticeships to respond to or anticipate labour market needs. The specific questions were tailored to the role of the interviewee. Thus, for example, questions addressed to school direc-

1 This number includes ten individuals who participated only in the round-table discussions and not in the interviews. Otherwise, round-table participants are a subset of the interviewees. 
tors and teachers included whether curricula were adjusted to reflect labour market needs, if information from the local/regional labour market and companies was utilized to make teaching more compatible with company needs, and whether there was a mismatch between the offer of and the demand for apprenticeship positions.

Typical questions addressed to company representatives included whether they had been approached by OAED to provide feedback on their skills needs, if they had communicated their skills needs to schools on their own initiative, and whether they would be willing to provide such information on a regular basis. Graduates were asked whether they recalled any instances of the content of their training being adjusted to the needs of local companies, if local professional associations or companies had been invited to their schools to talk to apprentices about current labour market needs, and whether, since graduating, they had been approached by schools to provide feedback on the skills needs of their companies and on their own professional development.

Although the second and third rounds prioritized other thematic areas (e.g. governance structures, and participation of and support for companies), issues associated with labour market responsiveness, such as selecting specialties and forming classes to match labour market needs or assessing the apprenticeship system and its outcomes, were also covered, with identical questions addressed to all participants. Typical questions addressed stakeholder views on possible cooperation with other key players; the best way to assess the system and its outcomes on a regular basis; whether the existing apprenticeship system contributed to identifying the necessary skills for apprentices, and how this contribution might be improved; whether curricula should, to some extent, reflect local or sectoral needs; and whether there was a role for their organization in monitoring work-based learning.

All interviews were recorded and transcribed, with care taken to protect the identity of all individuals.

Next, thematic content analysis was undertaken to identify and explore major themes within the data, i.e., patterns in the data that were important or interesting (see e.g. Braun \& Clarke, 2006; Nowell, Norris, White \& Moules, 2017). As mentioned above, this highlighted three major themes with regard to the labour market responsiveness of apprenticeships, i.e., content-related issues, actor-related issues, and issues related to the match between the offer of and demand for apprenticeship placements. The findings presented below are categorized according to these themes. 


\section{FINDINGS}

\section{Content-Related Issues}

Apprentices in Greece attend theoretical and lab-based courses at the EPAS for 21 hours a week and undertake practical training in the workplace for a maximum of six hours a day (Article 2 of Joint Ministerial Decision no. 40087/14 December 2007). In theory, the development of curricula is based on job profiles and occupational standards, which are in line with the priorities of national employment policies (Article 4 of Joint Ministerial Decision no. 110998/8 May 2006). In a similar vein, the specialties offered in the EPAS are assumed to be designed according to local labour market needs. Each year the Head of OAED decides how many apprenticeship positions will be offered, based on research within the local labour market in the geographical area of each EPAS (Articles 4 and 5 of Joint Ministerial Decision no. 40087/14 December 2007).

In practice, however, more than two-thirds of the interviewees in this study agreed that the content of curricula is only partly adapted to job profiles and occupational standards, and therefore does not always fully meet labour market needs. Furthermore, the interviews, especially those with teachers and school directors, indicated that matching curricula and specialties to labour market needs draws on a series of partly 'informal' actions, related to, for example, the review and revision of curricula by EPAS teachers, and decisions on the provision of specialties by OAED officials. Given that this informal activity takes place on a regular basis, it has become 'quasiinstitutionalized'.

The following extract from an interview with a teacher is revealing:

Especially in the case of specialties that involve the application of technology - for example, mechanics - there is a gap between the content of the courses and what the market needs. What happens in practice is that teachers, on their own initiative and in an ad hoc and informal manner, adjust the content of the courses they teach to better meet labour market needs. For this reason, teachers utilize information from the local labour market.

In a similar way, OAED officials take steps to match the specialties offered by the EPAS with labour market needs. This includes, inter alia, meetings, usually held in May, with representatives of social partners and chambers of industry and commerce, 
as well as personal research on local labour market needs, through the development of relationships and contacts with employers.

There was also general agreement amongst interviewees that the design and implementation of new curricula and specialties is time-consuming, mainly due to bureaucracy. As one school director stated: "The readjustment of curricula requires considerable time, as it involves bureaucratic procedures, in which the Ministry of Education and the Institute of Educational Policy play a key role." One of the teachers interviewed likewise underlined this point:"The creation and operation of a new specialty takes almost two years and it cannot keep up with the fast pace of the change in the labour market. In practice, what often happens is simply a repetition of the same specialties over time."

The above should be viewed in conjunction with the absence of an explicit learning plan for the company-based component of apprenticeships. Less than a tenth of graduates and two-tenths of company representatives said that companies followed a specific plan in the training of apprentices. This was illustrated by the words of one interviewee representing a large company active in the tourism sector:

In a large tourism company, such as ours, learning follows a specific plan and apprentices are required to fulfil a series of standardized tasks... This 'clarity' is something lacking in the vast majority of SMEs. Although the tripartite apprenticeship contract, signed by OAED, the employer and the apprentice, describes, in general terms, the rights and the duties of apprentices....training takes place in an ad hoc way.

Additional content-related constraints on the labour market responsiveness of apprenticeships in Greece, as discussed by approximately two-thirds of apprentices, are associated with the perceived gap between company- and school-based learning, with the latter often viewed as being out of date. This gap was seen as being most pronounced when company-based learning takes place at the premises of a private (and not public) sector employer.

Moreover, a small proportion of apprentices (about a tenth of those interviewed) complained that the training received at the company level did not reflect their specialty, with obvious implications for labour market responsiveness. For example, one of the graduates said: "I was supposed to be responsible for taking care of the infants at the nursery. Instead, the boss made me clean the kitchen and prepare coffee for the other employees." 


\section{Labour Market Responsiveness of Greek Apprenticeships: An Empirical Investigation}

The interviews with graduates indicated that this is a phenomenon more commonly associated with public rather than private sector employers.

Overall, the research revealed that the use - and especially the systematic use - of procedures aimed at enhancing the labour market responsiveness of apprenticeship programmes is limited. This is exemplified by the fact that, although more than half of graduates had the chance to visit the premises of companies during their studies, less than a tenth could recall any instances of local professional associations coming to an EPAS to talk about their skills needs. Moreover, graduates were not officially invited by their schools to provide feedback on the needs of the company they worked at after graduation, with one graduate interviewee saying, "Teachers only ask graduates informally for feedback from their work experience after graduation." Likewise, the vast majority of the company representatives interviewed had not been approached by OAED to provide information about the skills needs of their companies. Furthermore, there was no evidence that those who had been approached were surveyed in a structured manner. In fact, almost three-quarters of the companies that participated in the online survey said that they were familiar with the apprenticeship programmes offered by OAED. About half of the employers did, however, discuss their skills needs with OAED after they had taken the initiative.

The research also highlighted general agreement amongst interviewees that the severity of the financial crisis had contributed to the stagnation (or even aggravation) of the negative features of apprenticeships, and especially those related to schoolbased training. Furthermore, approximately a fifth of all interviewees mentioned that reduced financial resources, as a result of the crisis, worked against the updating of laboratories, books, and the hiring of permanent teachers, thus undermining the overall quality of apprenticeships and restricting their ability to attain their goals.

Finally, interviewees offered a series of suggestions for improving the market-responsiveness of apprenticeships. These included re-establishing the old OAED committees that were in charge of adapting curricula to labour market needs, collecting information from employers, on an annual basis, about the specialties they are interested in, and allowing employers to play a key role in the design of curricula.

\section{Actor-Related Issues}

There was general agreement amongst interviewees that major actors, especially social partners, chambers of industry and commerce, and employers, all of whom have a deep knowledge of the labour market, but a relatively weak presence in the 
existing governance structures, appear to operate in a way that hinders the labour market responsiveness of apprenticeships. The words of a social partner interviewee are revealing on this issue as they also highlight the willingness of actors with a limited engagement in apprenticeships to become more involved in the system:

In theory, social partners sit on OAED's Administration Board and thus they can directly influence the type and nature of measures, interventions and programmes that OAED develops and implements, including apprenticeships. Nonetheless, in practice....members of the Hellenic Confederation of Professionals, Craftsmen and Merchants (GSEVEE), that is to say owners of SMEs, are essentially the only ones who play a role in formulating the content of practical workplace training (and much less in shaping curricula)...We would like to be more involved, especially in the selection of specialties and the design of curricula. We know the market and have the necessary know-how to play that role.

The interviews with representatives of chambers of industry and commerce, as well as employers, likewise confirmed that the roles of these actors are relatively limited and that they would like to become more engaged in apprenticeships. For instance, according to a representative of a chamber of industry and commerce:

Currently, chambers of industry and commerce do not have the role that they would wish to play in the apprenticeship system...In collaboration with social partners, chambers could record labour market needs at regional and local levels. They could also play a key role in the provision of guidance at all levels, as well as in the governance of apprenticeships, for example, by registering companies interested in apprenticeship programmes.

Likewise, one employer said:

We are not satisfied with the rather limited role we play in the system. Companies would be interested in being more actively engaged in apprenticeships and in enhancing their labour market responsiveness, especially by having a say in the selection of specialties and the design of curricula. 


\section{Labour Market Responsiveness of Greek Apprenticeships: An Empirical Investigation}

The above should be viewed in conjunction with the performance of actors with stronger institutionalized responsibilities in the apprenticeship system, such as OAED's Centres for the Promotion of Employment (KPA), which presents further barriers to the labour market responsiveness of apprenticeships. This issue is discussed in the following extract from an interview with an OAED official:

Although the KPA provide EPAS with access to a comprehensive database that includes data on positions offered by companies, they have problems in fulfilling their role, since they suffer from understaffing. Moreover, they cannot provide updated data on the supply of and demand for labour at the local level.

Shortcomings in the role played by another group of stakeholders with a strong institutionalized role in the system, i.e., teachers, also work against the labour market responsiveness of apprenticeship programmes. In this case, as explained by one of the teachers interviewed, the main problem is the shortage of permanent teachers:

Given that EPAS teachers are diminishing in numbers, and the share of permanent staff is likewise decreasing, compared with the share of teachers paid by the hour, the operation of schools is essentially hampered, at the ultimate expense of the labour market responsiveness of apprenticeships. We should also bear in mind that only permanent staff have the authority to monitor workbased learning.

Finally, the research highlighted a series of suggestions made by interviewees. These included inter alia, strengthening the collaboration between teachers, KPA offices, ministries and other agencies engaged in apprenticeship programmes, and encouraging the involvement of chambers of industry and commerce in informing OAED about labour market needs.

\section{Match Between the Offer of and Demand for Apprenticeship Positions}

Given the findings presented above, the relative mismatch between the offer of and demand for apprenticeship positions, mentioned by most interviewees as a major weakness of apprenticeships in Greece, should not come as a surprise. One OAED official commented as follows: "In practice, the most important indicator of whether a specialty does not respond to labour market needs is the shortage of training posts 
offered by companies for that specialty (and vice versa). Unfortunately, this is not uncommon."

The majority of interviewees from all stakeholder groups also agreed that the existing popular specialties are limited to a narrow set of occupations and do not cater for emerging sectors of economic activity. Sectors with high growth forecasts are not fully embraced and supported by the development and expansion of relevant specialties. Broadly speaking, the apprenticeship offer is driven by the availability of resources (laboratories and teaching staff in particular) rather than identified labour market need.

The online survey carried out as part of the research corroborated the mismatch between the offer of and demand for apprenticeship positions. Although employers understand and recognize the importance of apprenticeships in ensuring a skilled labour force, the most common reason mentioned for companies not offering apprenticeship positions ${ }^{2}$ was the absence of appropriate specialty programmes and the related absence of graduates with the skills needed by companies. The top reason given by companies that stated they did not intend to offer apprenticeship posts in the future (less than one-tenth of respondents) was that apprentices lack the necessary skills (general and social competences especially, but also technical skills).

By contrast, when participants in the online survey were asked about the strengths of apprenticeships as opposed to other schemes, the most commonly mentioned feature was the lower cost of apprentices compared to the alternatives. Thus, it appears that the main reason for hiring apprentices is not their ability to fulfil the tasks linked to a job, but their perceived low cost - employers effectively see them as 'cheap labour'.

These findings should be viewed in conjunction with the concerns expressed by employers with regard to the skills of apprentices. Although more than two-thirds of apprentices and graduates believed that the competences they developed during their studies would help them (or had helped them) at least to find a first job in their chosen profession in the local labour market, more than half of the company representatives interviewed stated that apprentices lack important skills. For instance, one company representative said: "Receptionists are not in the position to use specialized IT programmes."

While there was general agreement amongst interviewees from all groups of stakeholders about the lack of a comprehensive strategy for strengthening the labour market responsiveness of apprenticeships, as reflected in the content- and actor-related issues discussed in the previous subsections, approximately a fifth of interviewees

\footnotetext{
2 Participants were able to provide multiple answers to this (and other) questions in the online survey.
} 


\section{Labour Market Responsiveness of Greek Apprenticeships: An Empirical Investigation}

argued that the mismatch between the offer of and demand for apprenticeship positions was largely associated with the ongoing financial crisis. For instance, as a result of the financial situation in Greece it is not possible for all apprentices to get company-based training. An OAED official interviewed said:

It is true that in some cases demand for apprenticeship positions exceeds what is actually offered by companies (e.g. hairdressing), while companies often face difficulties in finding apprentices for a number of specialties (e.g. aircraft-related specialties). The crisis has further limited the ability of companies, especially SMEs which make up the bulk of companies in Greece, to offer apprenticeship positions.

In general, representatives of social partners, along with employers, tended to more readily acknowledge the mismatch between the offer of and demand for apprenticeship positions, compared with representatives of national agencies involved in apprenticeship programmes. Furthermore, they stressed their willingness to collaborate with other stakeholders in order to deal with this problem. According to a social partner interviewed:

Cooperation with other stakeholders would work against the mismatch between offer and demand that characterizes the existing apprenticeship system. There is no doubt that we would be open to cooperation... especially with regard to the selection of specialties.

By contrast, representatives of national agencies engaged in apprenticeships were more cautious in acknowledging such weaknesses. Moreover, they tended to focus on the efforts made to address the situation, as illustrated by the following quote from an employee at the Ministry of Labour, Social Insurance and Social Solidarity:

Although we cannot deny that there is some distance between the offer of and demand for apprenticeship positions, the Ministry does whatever possible to cope with this, including collaborating with the Ministry of Education, the prefectures, social partners, and chambers of industry and commerce. In the framework of the newly established mechanism for the identification of labour market needs, the Ministry of Labour, which also supervises OAED, plays a coordinating role. 
Finally, the research revealed the existence of a broad consensus on the importance of monitoring the professional evolution and career development of apprentices on a regular basis, as a means to evaluate apprenticeships and address the existing mismatch between the offer of and demand for apprenticeship positions. Although in theory OAED and EPAS teachers are responsible for monitoring and evaluating the outputs of apprenticeship schemes (Article 2 of Joint Ministerial Decision no. $1.7195 / 3.1289 / 27$ May 2011), the interviews indicated that, in practice, monitoring and evaluation is largely done in a non-systematic manner.

There was, however, disagreement on the most appropriate way to carry out monitoring and evaluation. Some interviewees spoke of the need for the combined use of external and internal advisors, while others favoured the use of exclusively internal advisors. All interviewees agreed that, in the case of internal monitoring and evaluation, OAED Directorates, such as the Directorate of Education and the Directorate of Programmes of Studies, should be in charge.

One of the main additional suggestions made by interviewees was that the findings of studies analysing the existing mismatch between the offer of and demand for apprenticeship positions should be disseminated more widely.

\section{DISCUSSION AND CONCLUSIONS}

Based on the findings of a large-scale, mostly qualitative research project which reviewed apprenticeships in Greece from a multi-stakeholder perspective, this article sought to fill a significant gap in the literature and shed light on a largely unexplored but crucial aspect of apprenticeships in this country: labour market responsiveness. In particular, the focus of the work was on three major themes which emerged from the data analysis: content-related issues, actor-related issues, and the mismatch between the offer of and demand for apprenticeship positions.

The article highlighted a number of strengths of Greek apprenticeships, such as the relevance of the knowledge acquired during apprenticeships, at least as regards starting out in a profession, and the willingness of employers and other actors to become more engaged in apprenticeships. However, it also found weaknesses that overshadowed these strengths. These weaknesses included, inter alia, the largely informal character of the procedures for updating curricula and specialties and thus making the content of learning more compatible with labour market needs; the time- 
consuming, and also rather restricted nature of the existing formal procedures for enhancing labour market responsiveness; the lack of flexibility to support the specialties that are needed, and integrate them into the local labour market; and the gap between school- and company-based learning. The limited role played by actors with in-depth knowledge of the labour market, such as social partners, as well as shortcomings in the performance of actors with a clearer institutional role in the system, such as teachers, create further problems.

Moreover, there is a strong mismatch between the offer of and demand for apprenticeship positions. This mismatch should be viewed in conjunction with the concerns expressed by employers about the skills of apprentices and the essential lack of standardized processes for the regular monitoring and evaluation of apprenticeship outputs. Overall, the research revealed a gap between theory and practice and a lack of clear-cut systematic approaches to enhancing the labour market responsiveness of apprenticeships in Greece.

The findings from the empirical investigation undertaken, as presented in this exploratory article, corroborate some ofthe main findings and conclusions presented in the literature discussed in the introductory section above. These include, for instance, the positive impact of apprenticeships on the skills of apprentices, at least with regard to equipping them to take a first step into the labour market, and the acknowledgement that the minimal roles played by actors with deep knowledge of the labour market, such as social partners and chambers of industry and commerce, alongside the mismatch between the offer of and demand for apprenticeships, pose serious obstacles to improving the labour market responsiveness of apprenticeships.

High quality content, e.g. up-to-date curricula and specialties, and close relationships between those involved in delivering the school- and company-based training components, is likewise recognized as having a positive impact on the labour market responsiveness of apprenticeships. Similarly, the rather low level of employer satisfaction in terms of the skills of apprentices, as well as the negative effect of the recent financial crisis on the content of apprenticeship programmes and the stance of companies towards apprenticeships are also consistent with previous research findings.

Research participants also made a series of recommendations aimed at improving the labour market responsiveness of apprenticeship programmes in Greece. These include, inter alia, the following: re-establishing the old OAED committees, which were responsible for adapting curricula to labour market needs; strengthening the collaboration between teachers, KPA offices, ministries and other agencies engaged 
in apprenticeship programmes; and disseminating more widely the findings of studies analysing the existing mismatch between the offer of and demand for apprenticeship positions.

Naturally, regardless of its originality and novelty, the research is not without limitations. To a large extent, these reflect the broadly recognized limitations of qualitative research related, in particular, to the potential for generalizing from the research findings. Nevertheless, the results summarized here could form a crucial baseline for the future evaluation of apprenticeships, especially in light of the newly acquired interest of national and EU authorities in this type of training programme. Building on the current study, further research could, for example, explore the possible effects of recent policy developments in Greece concerning the labour market responsiveness of apprenticeships.

At a first glance, these developments, largely included in the 2017 QFA, appear promising. The Ministry of Labour is expected to take into account the proposals of the newly created 'National Coordinating Body for Apprenticeships', which should have a positive impact on the identification of national labour market needs.

Local Apprenticeship Partnerships will be in charge of identifying local labour market needs, providing apprentices with guidance concerning labour market access, and monitoring the integration of graduates into the local labour market. Social partners are expected to provide feedback on labour market needs in different sectors, whilst OAED will be responsible for research on the labour market transitions and professional careers of graduates. Furthermore, the use of graduate employment rates as a key indicator for the evaluation of apprenticeships sounds hopeful.

Yet, in reality, the landscape with regard to the labour market responsiveness of apprenticeships remains to a large extent vague. For instance, the mechanism for the identification of labour market needs developed by the Ministry of Labour was created to guide the design and implementation of employment policies in general, rather than to serve the needs of apprenticeships in particular. It is therefore doubtful whether this mechanism will be effective in enhancing the labour market responsiveness of apprenticeship programmes.

Moreover, there is no clear process governing the request and use of relevant data from the mechanism. As a result, major actors involved in apprenticeships have essentially no access to current or future research outputs.

It is also unclear whether the key system-level responsibilities of national bodies, such as the National Coordinating Body for Apprenticeships mentioned above, will 
include the selection of specialties, and ensuring that these specialties are compatible with labour market needs. Additionally, processes and formal requirements to adapt the content of curriculahave not been put in place.

The continuing shortage of permanently employed teachers is another serious challenge to the labour market responsiveness of apprenticeship programmes. Policy-makers should acknowledge that teachers can play a key role in offering training in specialties that are in demand in emerging sectors of the economy, and that understaffed schools undermine any efforts to restructure apprenticeships. Furthermore, there are no signs that the employer perception of apprentices as cheap labour is changing; nor is there a clear-cut strategy to bring about such a change.

Lastly, the success of the initiatives outlined above may be put at risk by the the notoriously slow pace of reform in Greece.

Overall, although a thorough examination of recent policy developments regarding apprenticeships is a task for future researchers, the work carried out for this research suggests a rather limited and fragmented picture. Hence, successfully tackling the severe shortcomings of apprenticeships in Greece with regard to labour market responsiveness remains an open bet.

In this regard, this article, which identified strengths in Greek apprenticeship programmes as well as weaknesses which undermine those strengths, and highlighted the need for urgent policy action to make apprenticeships more labour market-oriented, shows the way ahead. It underlines the need to address the shortcomings of apprenticeship programmes in Greece, by incorporating the suggestions of interviewees, such as allowing employers and other key stakeholders to become more engaged in apprenticeships.

Above all else, however, the present article essentially emphasizes the importance of adopting a comprehensive strategy aimed at enhancing the labour market responsiveness of apprenticeships in crisis-ridden Greece. Without such an approach, the efforts to promote apprenticeship programmes as an alternative to an academic educational pathway for young people will be seriously jeopardized. 


\section{REFERENCES}

Albanese, A., Cappellari, L., \& Leonardi, M. (2017). The Effects of Youth Labour Market Reforms: Evidence From Italian Apprenticeships. IZA Discussion Paper Series, No. 10766.

Bellmann, L., Gerner, H.-D., \& Leber, U. (2014). Firm-Provided Training During the Great Recession. Jahrbücher für Nationalökonomie und Statistik, 234(1), 5-22.

Braun, V., \& Clarke, V. (2006). Using Thematic Analysis in Psychology. Qualitative Research in Psychology, 3(2), 77-101.

Cedefop. (2015). Briefing Note. Making Apprentices Work for Small and Medium Enterprises. Thessaloniki, Greece: Cedefop. Retrieved from http://www.cedefop. europa.eu/files/9102 en.pdf

European Commission. (2015). Memorandum of Understanding Between the European Commission Acting on Behalf of the European Stability Mechanism and the Hellenic Republic and the Bank of Greece. Retrieved from https://ec.europa.eu/ info/sites/info/files/01 mou 20150811 en1.pdf

European Commission. (2017). Press Release, "Commission Adopts Initiative to Boost Apprenticeships in Europe”. Retrieved from http://europa.eu/rapid/pressrelease IP-17-3585 en.htm

Foundation for Economic and Industrial Research. (2015). Apprenticeship Systems in Greece and Europe and their Funding Dimension. Athens, Greece: Foundation for Economic and Industrial Research (in Greek).

Fuller, A., Unwin, L., Cavaglia, Ch., McNally S., \& Ventura, G. (2017). Better Apprenticeships. Access, Quality and Labour Market Outcomes in the English Apprenticeship System. London, United Kingdom: The Sutton Trust. Retrieved from https:// www.suttontrust.com/wp-content/uploads/2017/11/Better-Apprenticeships-1. pdf

Gambin, L., Hogarth, T., \& Hasluck, C. (2011). Maximizing Apprenticeship Completion Rates in England. Canadian Apprenticeship Journal, 4. 
Grollmann, P., Steedman, H., Jansen, A., \& Gray, R. (2017). Building Apprentices' Skills in the Workplace: Car Service in Germany, the UK and Spain. London, United Kingdom: Centre for Vocational Education Research, London School of Economics \& Political Science. Research Discussion Paper 011. Retrieved from http://cver.lse.ac.uk/textonly/cver/pubs/cverdp011.pdf

Hogarth, T., Gambin, L., \& Hasluck, Ch. (2011). Apprenticeships in England: What Next?. Journal of Vocational Education and Training, 64(1), 41-55.

Ministry of Labour, Social Insurance and Welfare. (2015). Support for the Implementation of Actions for the Upgrading of OAED's Apprenticeship. OAED's Apprenticeship: Trends, Evolution, Potentials, Reforming Apprentices (in Greek).

Mulkeen, J., Abdou, H., Leigh, J., \& Ward, P. (2017). Degree and Higher Level Apprenticeships: An Empirical Investigation of Stakeholder Perceptions of Challenges and Opportunities. Studies in Higher Education. Retrieved from http:// usir.salford.ac.uk/43440/9/Degree\%20and\%20Higher\%20Level\%20Apprenticeships\%20an\%20empirical\%20investigation\%20of\%20stakeholder\%20perceptions $\% 20$ of $\% 20$ challenges $\% 20$ and $\% 20$ opportunities.pdf

Nowell, L. S., Norris, J. M., White, D. E., \& Moules, N. J. (2017). Thematic Analysis: Striving to Meet the Trustworthiness Criteria. International Journal of Qualitative Methods, 16(1), 1-13.

OECD. (2014). G20-OECD-EC Conference on Quality Apprenticeships for Giving Youth a Better Start in the Labour Market. Background Paper Prepared by the OECD. OECD Conference Centre, Paris, 9 April 2014. Retrieved from https:// www.oecd.org/els/emp/G20-OECD-EC\%20Apprenticeship\%20Conference Issues\%20Paper.pdf

Paidoussi, C. (2014). Dual System of Vocational Training: The German Narrative Regarding the Connection Between Education and the Labour Market. Articles and Studies 10/2014. Athens, Greece: Institute of Labour and Human Resources (in Greek).

Parey, M. (2016). Vocational Schooling Versus Apprenticeship Training. Evidence from Vacancy Data. Annual Conference 2016 (Augsburg): Demographic Change 145655, Verein für Socialpolitik /German Economic Association. 
Piopiunik, M., \& Ryan, P. (2012). Improving the Transition Between Education/Training and the Labour Market: What Can We Learn From Various National Approaches?. European Expert Network on Economics of Education (EENEE) Analytical Report, 13 (Prepared for the European Commission).

Rowe, L., Moss, D., Moore, N., \& Perrin, D. (2017). The Challenges of Managing Degree Apprentices in the Workplace: A Manager's Perspective. Journal of Work-Applied Management, 9(2), 185-199.

Small Enterprises Institute of the Hellenic Confederation of Professionals, Craftsmen, and Merchants. (2014). Vocational Education and Training in Greece. Weaknesses, Potential and Prospects. Athens, Greece: Small Enterprises Institute of the Hellenic Confederation of Professionals, Craftsmen, and Merchants (in Greek).

Wolter, S. C., \& Ryan, P. (2011). Apprenticeship. In E. A. Hanushek, S.J. Machin, \& L. Woessmann (Eds.), Handbook of the Economics of Education, 3, 521-576. Elsevier. 